\title{
ALÔ, QUEM FALA?
}

Esta publicação sinaliza caminhos, constrói pontes e abre atalhos para uma temática bastante cara nos dias de hoje: a importância em ouvir, observar e dialogar com o universo da criança. No entanto, ainda que as práticas de escuta infantil estejam cada vez mais disseminadas em esferas e ambientes distintos, no público e no privado, na cidade, na escola e em instituições diversas, é urgente ampliar o debate sobre questões que iluminam abordagens históricas, metodológicas e éticas.

Quem está na escuta? reúne artigos de pesquisadores que atuam em diferentes áreas e quem abre a discussão, numa entrevista exclusiva, é Manuel Jacinto Sarmento, professor em Sociologia da Infância da Universidade do Minho, de Portugal. Ele trata da participação infantil na cidade e da representação da infância nos dias de hoje no texto intitulado Retrato em positivo. Para Sarmento, é urgente estabelecer uma relação recíproca, de fala e de escuta, entre adultos e crianças.

Assim como Ariadne, a educadora e antropóloga Adriana Friedmann, idealizadora do Mapa da Infância Brasileira, aponta caminhos em $A$ arte de adentrar labirintos infantis. Escutar as crianças, diz a pesquisadora, é como fazer uma viagem ao território da infância. No percurso pelos universos infantis, o viajante descobre diversidade de linguagens, costumes, sabores, cheiros, músicas, danças, brincadeiras, histórias e paisagens. Assim, ao escutar e descobrir o que as crianças têm a dizer, novos mundos e repertórios descortinam-se à frente do adulto.

Para ouvir as crianças, no entanto, é preciso estar atento à Poética da infância. Nesse artigo, os professores e pesquisadores Severino Antônio e Katia Tavares tratam de uma educação em que as crianças possam pensar, sentir e se expressar poeticamente. Os autores defendem que as crianças, principalmente as pequenas, exercitam espontaneamente um pensamento mitopoético, em que tudo fala, assim como se transforma em tudo. 
Em Tessitura de vínculos em campo, os documentaristas David Reeks e Renata Meirelles, coordenadores do Território do Brincar, abordam as relações entre pesquisador e criança em momentos de encontros marcados pelo espontâneo, num banho de rio ou compartilhando brincadeiras. Contam que há uma busca genuína em revelar-se como pessoa, antes mesmo de se mostrar em papéis como pesquisador, educador ou fotógrafo na missão de dar voz às crianças. A "fala" da criança, aliás, extrapola a oralidade. E, assim, os gestos infantis expressam verdades do humano.

Dos gestos aos olhares. Radiografando uma espécie de etnografia literária e poética, a jornalista e documentarista Gabriela Romeu, uma das idealizadoras do Infâncias, traça perspectivas da observação em Narrativas do olhar (notas de um diário). Com que olho eu olho? Numa multiplicidade do visivel, a pesquisadora empresta olhos de diferentes personagens da literatura para experimentar escutar longe e espiar além, provocando deslocamentos e desestabilizando certezas nos processos.

Os sentidos de ouvir foram também ampliados. A arte-educadora Lindalva Souza, coordenadora do Vozes da Infância Brasileira (VIB), traça rotas diversas para uma escuta lúdica, que inclui criação de mapas, construção de objetos, oficina de desenhos e brincadeiras de faz de conta. Para compartilhar as muitas formas de "ouvir" meninos e meninas de diversas instituições de São Paulo, o convite é percorrer o texto Cartografia de uma escuta sensivel.

Mas há ainda mais rotas e caminhos para trilhar: outras experiências de escuta infantil ao longo das páginas são ricas fontes de inspiração. E, para quem ainda tiver fôlego, vale seguir a jornada com referências de livros, sites e filmes que fomentam a discussão.

Boa viagem! Boa leitura!

\section{PARA NAVEGAR MAIS}

Sempre que aparecer este código, também chamado QR Code, é sinal que ali há mais

informações para descobrir e navegar. Para ter acesso ao conteúdo, é preciso dispor de uma câmera em um telefone celular e um programa feito para ler o código. Depois, basta apontar o leitor do celular para a imagem que 0 aplicativo rapidamente converte o código e carrega um link.
MAPA DA INFÂNCIA BRASILEIRA

www.mapadainfanciabrasileira.com.br 